The sedentary habits of the female scales leave the natural dispersal of these insects to the first instar larvæ so that, except for accidental carriers, the spread is characterized by its thoroughness rather than by its breadth.

The most congenial conditions for the coccids are found in warm climates, and there are comparatively but few species whose life cycles are attuned to regions having severe winters.

\title{
5. THE LIFE CYCLE OF THE LEPIDOPTERA.
}

\author{
S. B. Fracker, \\ Madison, Wis.
}

Coming at the point in this program between discussions of heterometabolous and holometabolous development, it seems necessary for us to diverge a few moments from the subject as printed, to consider the biological significance of complete metamorphosis.

The structural basis for the distinction between these two types of development has been repeatedly described. Studies histological, morphological, and physiological, have been made on the ontogeny of the different parts of the insect body, in ametabola, heterometabola, and holometabola. Uniformity has been discovered in wing development, cell structure, and body sclerites within each of these groups until we may say that the basis for the three great subclasses of insects rests on a solid foundation in morphology.

The biological significance of these groups, on the other hand, has usually been overlooked. The environmental problems which evolution is called upon to solve, if we may be permitted to express the situation in this way, become immensely complicated as the number of different forms taken on by a single individual increases.

Speaking biologically then, insects without metamorphosis exist in, and are thus adapted to, a single environment, both the form and the surroundings remaining the same throughout the life of the individual. With the arrival of wings, an increase in the number of activities causes an enlargement of horizon and introduces some degree of variety in the character of the 
surroundings. Typically, heterometabola, except when aquatic, retain the same environment throughout life and the adults face practically the same ecological conditions as do the immature, wings simply increasing the chances of survival.

Insects with complete metamorphosis all differ from those with incomplete, in one respect: to each individual three environmental problems are presented. The larva must find an adequate food supply, the pupa protection against enemies and hostile physical conditions, and the adult opportunity and means for reproduction. The abundance of the available food, which includes every kind of organic matter, elaborated in any way by any vegetable or animal organism, reduces the complexity of the situation. Rapidity of locomotion, however, one of the most effective means of escaping adverse conditions, has been uniformly reduced or lost in holometabolous insects. For the latter, therefore, the problem of utilizing the food supply is one of protection against enemies and weather during the period of growth.

If we now turn our attention to the position of the Lepidoptera among other holometabola we find that the four major orders have solved this problem of protection in four different ways. The Coleoptera use the combative method of fighting the struggle for existence. Clad in armor in both larval and adult stages they exist on the hardest wood, prey on the most agile insects, or burrow within the soil. The Diptera, on the other hand, have adopted the path of least resistance. While the armed beetle larva hides in caves and burrows, the dipterous maggot is concealed deep in rotting vegetation, in the stomachs of mammals, or the body juices of other insects. Even the predacious Syrphid larvæ attack only the softest, most helpless of all insects, the plant lice.

Hymenopterous larvæ, excepting the Tenthredinoidea, have, if anything, gone farther. Many still "rustle for themselves" but in the more specialized predatory families even the host insects must be paralyzed by the parents before the larvæ can successfully attack them. Finally the last step is reached among the bees and ants where the young must be fed, warmed and cared for day by day, so utterly helpless that they can not even be furnished with an adequate supply of food and left to consume it alone. 
Of all the major orders, in only one, the Lepidoptera, have the larvæ attempted to meet the conditions of life as it exists and, with minimum protection, succeeded solely through their immense vitality.

If the uniformity within each dominant order is remarkable, the variety is no less so. The differences between the nearly fifteen thousand species of Coleoptera in the United States are primarily variations in essential chitinized structures. Number and position of legs true and false, number of claws, shape and arrangement of mouthparts, head skeleton, cerci, and chitinized plates are all evident. In the Diptera structural differences are equally numerous; the soft parts such as body shape, and the respiratory system are also various. Dipterous larvæ depart farther from typical arthropod structures than other orders.

In the Hymenoptera structural divergences (once more excepting Tenthredinoidea) almost disappear and variation in social organization and methods of securing food take their place.

Again the Lepidoptera are unique. With a fundamental structure so constant that logical classification long appeared to be baffling, superficial differences in the larvæ are extremely numerous. One finds remarkable uniformity in all the principal features of anatomy. The same number and position of thoracic legs and prolegs, the latter nearly always with chitinized hooks, the same form of head, the same kind of mouthparts, the same number of spiracles and segments. Exceptions, except among the few leafminers, are trifling.

In superficial characters the reverse condition, variety, is just as marked. Using one fundamental setal pattern, the most diverse arrangements are presented. A sensitive area in one family develops a single seta, in another, a tuft on a wart, in another, a group of soft hairs on a flat plate, and in still another, a bunch of poisonous spines. If we examine the arrangement of the hooks on the prolegs we will note variations equally significant.

\section{FOOD SUPPLY}

Table I shows the remarkable uniformity in source of food supply in the Lepidoptera. The members differ from other orders in being confined almost entirely to chlorophyll-bearing plants. The exceptions are entirely among the more primitive 
microlepidoptera. In the families in which the mode of life has become static, the species are limited not only to the kind of plant, but are, except in a few Noctuidæ, confined almost wholly to leaves of terrestrial flowering species.

TABLE I. FOOD SUPPLY.

\begin{tabular}{|c|c|c|c|c|c|c|c|c|c|c|c|c|c|c|c|}
\hline \multirow{4}{*}{$\begin{array}{c}\text { ORDER, } \\
\text { FAMILY, OR } \\
\text { SUPER-FAMILY }\end{array}$} & \multicolumn{10}{|c|}{ Plant Material } & \multicolumn{5}{|c|}{ Animal Material } \\
\hline & \multicolumn{5}{|c|}{$\begin{array}{l}\text { Living Terrestrial } \\
\text { Flowering Plants }\end{array}$} & \multicolumn{2}{|c|}{$\begin{array}{c}\text { Aquatic } \\
\text { Plants }\end{array}$} & \multicolumn{2}{|c|}{$\begin{array}{l}\text { Dead Plant } \\
\text { Material }\end{array}$} & \multirow{3}{*}{ 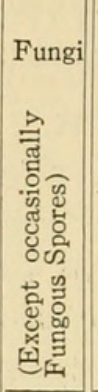 } & \multirow{2}{*}{\multicolumn{2}{|c|}{$\begin{array}{l}\text { Living } \\
\text { Parasites } \\
\text { or } \\
\text { Predators }\end{array}$}} & \multirow{3}{*}{ 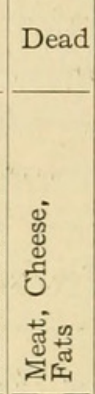 } & \multirow{3}{*}{ 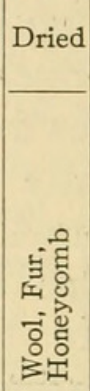 } & \multirow{3}{*}{ 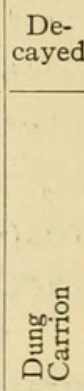 } \\
\hline & \multirow[b]{2}{*}{ 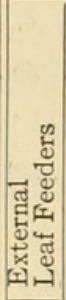 } & \multicolumn{4}{|c|}{ Borers } & \multirow[b]{2}{*}{ 离 } & \multirow{2}{*}{ 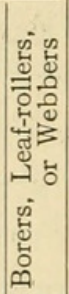 } & \multirow{2}{*}{ 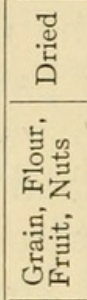 } & \multirow{2}{*}{ 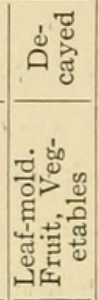 } & & & & & & \\
\hline & & 总 & 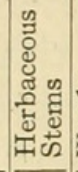 & 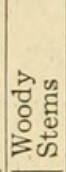 & 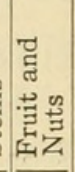 & & & & & & & 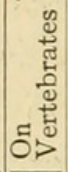 & & & \\
\hline $\begin{array}{l}\text { NEUROPTERA.. } \\
\text { MECOPTERA... } \\
\text { TRICHOPTERA. } \\
\text { LEPIDOPTERA. }\end{array}$ & $\ddot{x}$ & $\ddot{x}$ & $\ddot{x}$ & $\ddot{x}$ & $\ddot{x}$ & $\begin{array}{l}\ddot{X} \\
(\mathrm{X})\end{array}$ & $(\mathrm{X})$ & $(\mathrm{X})$ & & & $\begin{array}{l}\mathrm{X} \\
\mathrm{X} \\
\mathrm{X} \\
(\mathrm{X})\end{array}$ & & & & \\
\hline $\begin{array}{l}\text { Pyralidoidea........ } \\
\text { Zygaenoidea....... }\end{array}$ & $\begin{array}{l}\dddot{X} \\
\mathrm{X} \\
\mathrm{X} \\
\mathrm{x}\end{array}$ & $\begin{array}{c}\mathrm{x} \\
\cdots \cdots \\
\cdots \cdots \\
\cdots \\
\mathrm{x} \\
\cdots \\
\cdots \\
\end{array}$ & $\begin{array}{c}\cdots \\
\cdots \\
x \\
\mathrm{X} \\
\cdots \\
\cdots\end{array}$ & $\begin{array}{l}\cdots \\
\cdots \\
\cdots \cdots \\
\cdots \cdots\end{array}$ & $\mid \begin{array}{c}\mathrm{X} \\
\mathrm{X} \\
\cdots \\
\cdots \\
\cdots \\
\mathrm{X} \\
\mathrm{X} \\
\cdots \\
\end{array}$ & $\begin{array}{l}\dddot{\mathrm{X}} \\
\cdots\end{array}$ & $\ddot{x}$ & $\begin{array}{l}\cdots \\
\mathrm{X} \\
\mathrm{X} \\
\cdots \cdots\end{array}$ & & & $\begin{array}{l}\dddot{\mathrm{X}} \\
\mathrm{X}\end{array}$ & $\begin{array}{l}\cdots \\
\cdots \\
\cdots \\
\cdots\end{array}$ & & 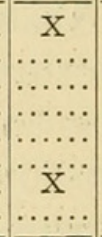 & $\begin{array}{l}\cdots \cdot \\
\cdots \cdot \\
\cdots \cdot \\
\cdots \cdots \\
\cdots \cdots \\
\cdots \cdots \\
\cdots\end{array}$ \\
\hline $\begin{array}{l}\text { Geomet } \\
\text { Lasiocar } \\
\text { Liparida } \\
\text { Notodor } \\
\text { Noctuid } \\
\text { Arctiida }\end{array}$ & $\begin{array}{l}\mathrm{X} \\
\mathrm{X} \\
\mathrm{X} \\
\mathrm{X} \\
\mathrm{X} \\
\mathrm{X} \\
\mathrm{X} \\
\mathrm{X}\end{array}$ & $\begin{array}{l}\cdots \\
\cdots \cdots \\
\cdots \cdots \\
\cdots \\
\cdots\end{array}$ & $\begin{array}{l}\cdots \\
\mathrm{X} \\
\cdots \\
\cdots \\
\cdots\end{array}$ & $\begin{array}{l}\cdots \\
\cdots \cdots \\
\cdots \cdots \\
\cdots \\
\cdots\end{array}$ & \begin{tabular}{c}
$\cdots$ \\
\hdashline $\mathrm{X}$ \\
$\cdots$ \\
$\cdots$ \\
$\cdots$
\end{tabular} & $\begin{array}{l}\because \\
\because \\
\because \\
\because\end{array}$ & $\ddot{x}$ & & & & & 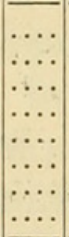 & $\begin{array}{l}. . \\
\cdots \\
\cdots \\
\cdots\end{array}$ & 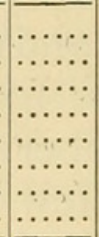 & $\begin{array}{l}\cdots \\
\cdots \\
\cdots . \\
\cdots \\
\cdots \\
\cdots \\
\cdots \\
\cdots \\
\end{array}$ \\
\hline $\begin{array}{l}\text { Hesperioidea....... } \\
\text { Lycaenoidea..... } \\
\text { Nymphaloidea.... } \\
\text { Pieridae......... } \\
\text { Papilionoidea..... }\end{array}$ & $\begin{array}{l}\mathrm{X} \\
\mathrm{X} \\
\mathrm{X} \\
\mathrm{X} \\
\mathrm{x}\end{array}$ & $\cdots$ & $\begin{array}{l}\cdots \\
\cdots \\
\cdots \\
\cdots \\
\cdots\end{array}$ & $\begin{array}{l}\cdots \\
\cdots \\
\cdots \\
\cdots \\
\cdots\end{array}$ & $\mid \cdots$ & & & & & & & $\mid \begin{array}{l}\cdots \\
\cdots \\
\cdots \\
\cdots \\
\cdots\end{array}$ & & $\cdots \cdots \cdots$ & $\cdots$ \\
\hline
\end{tabular}

Note-Parentheses indicate rare or unusual sources of food for the group named.

Returning to our original figure of speech, nature has taken a fundamental structure and a relatively constant environment and through superficial modifications has developed a great dominant order. She has exposed the members to every form of attack from parasites and enemies. She has made them both conspicuous and slow, with only moderate fecundity. But by providing them with the most universal and abundant source of food she has so developed their vitality that they have become 
one of the four largest groups of ordinal rank in the animal kingdom.

The few exceptions to the phytophagous habit include such very rare parasites as the Xylorictidæ, and a few predators such as one or two pyralids living on scale insects. Possibly the clothes-moths and the wax moths, living on animal products, might also be called carnivorous. None are parasites on living vertebrates.

TABLE II. MEANS OF PROTECTION.

\begin{tabular}{|c|c|c|c|c|c|c|c|c|c|c|c|c|c|c|c|}
\hline \multirow[b]{3}{*}{$\begin{array}{c}\text { ORDER, } \\
\text { FAMILY, OR } \\
\text { SUPER-FAMILY }\end{array}$} & \multirow{2}{*}{\multicolumn{7}{|c|}{ Structural }} & \multicolumn{8}{|c|}{ EXTERNAL } \\
\hline & & & & & & & & \multicolumn{5}{|c|}{ NATURAL } & \multicolumn{3}{|c|}{ Artificlal } \\
\hline & 鴛 & 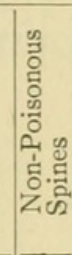 & 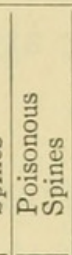 & 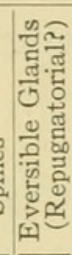 & 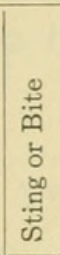 & 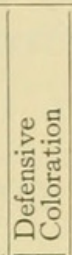 & 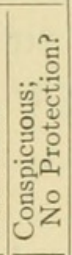 & 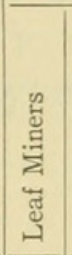 & 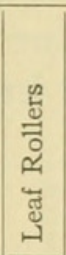 & 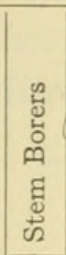 & 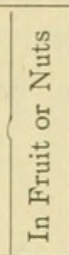 & 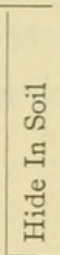 & 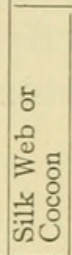 & 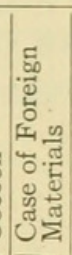 & 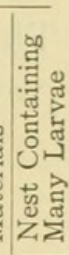 \\
\hline 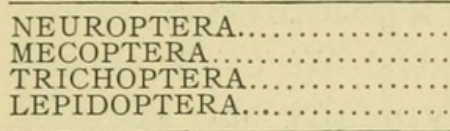 & $\mathrm{x}$ & $\mathrm{X}$ & $\ddot{x}$ & $\begin{array}{l}\mathrm{x} \\
\mathrm{x}\end{array}$ & $\begin{array}{l}\mathrm{X} \\
\mathrm{X} \\
\cdots \\
\cdots\end{array}$ & $\mathrm{X}$ & $\mathrm{X}$ & $\mathrm{x}$ & $\mathrm{x}$ & $\mathrm{x}$ & $\cdots$ & $\begin{array}{l}\mathrm{X} \\
\mathrm{X}\end{array}$ & $\mathrm{x}$ & $\begin{array}{l}\mathrm{X} \\
\mathrm{X}\end{array}$ & $\begin{array}{l}\cdots \\
\cdots \\
\mathrm{X}\end{array}$ \\
\hline 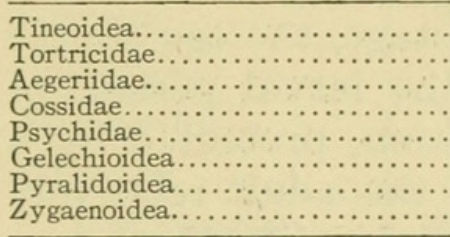 & $\begin{array}{l}\ldots . \\
\cdots \cdots \\
\cdots \cdots \\
\cdots \cdots \\
\cdots \\
\dddot{x} \\
\mathrm{x} \\
\end{array}$ & 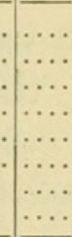 & $\begin{array}{l}\cdots \\
\cdots \cdots \\
\end{array}$ & $\mathrm{x}$ & $\begin{array}{l}\cdots \\
\cdots \\
\cdots \\
\cdots \\
\cdots \\
\cdots \\
\cdots\end{array}$ & $\begin{array}{c}\mathrm{X} \\
\cdots \\
\cdots \\
\dddot{\mathrm{X}} \\
\mathrm{X} \\
\cdots\end{array}$ & $\begin{array}{c}\cdots \\
\cdots \\
\mathrm{x} \\
\cdots \\
\cdots \\
\cdots\end{array}$ & $\begin{array}{c}\mathrm{x} \\
\cdots \cdots \\
\cdots \\
\cdots \\
\cdots \\
\cdots \\
\cdots \\
\cdots \\
\cdots \\
\end{array}$ & $\begin{array}{c}\mathrm{X}^{\mathrm{X}} \\
\cdots \\
\cdots \\
\cdots \\
\mathrm{X} \\
\mathrm{X} \\
\cdots \\
\end{array}$ & $\begin{array}{c}\cdots \\
\dddot{\mathrm{x}} \\
\mathrm{x} \\
\cdots \\
\cdots \\
\mathrm{x} \\
\cdots \\
\cdots\end{array}$ & $\begin{array}{c}\mathrm{X} \\
\mathrm{X} \\
\cdots \\
\cdots \\
\cdots \\
\cdots \\
\mathrm{X} \\
\cdots \\
\cdots\end{array}$ & 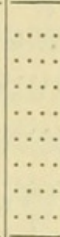 & $\begin{array}{c}\mathrm{x} \\
\cdots \\
\cdots \\
\cdots \\
\cdots \\
\cdots \\
\mathrm{X} \\
\cdots \\
\cdots \\
\end{array}$ & $\begin{array}{c}\mathrm{x} \\
\cdots \\
\cdots \\
\mathrm{X} \\
\mathrm{x} \\
\mathrm{x} \\
\cdots\end{array}$ & $\begin{array}{c}\dddot{x} \\
\cdots \\
\cdots \\
\cdots \\
x \\
\cdots \\
\cdots\end{array}$ \\
\hline 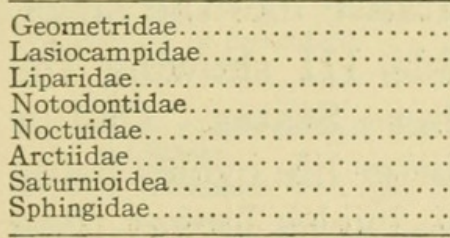 & $\begin{array}{l}\mathrm{x} \\
\mathrm{X} \\
\mathrm{X} \\
\mathrm{X} \\
\mathrm{X} \\
\cdots \\
\cdots \\
\end{array}$ & $\mid \begin{array}{l}\cdots \\
\cdots \\
\mathrm{x} \\
\cdots \\
\dddot{\mathrm{x}} \\
\cdots\end{array}$ & $\begin{array}{l}\ddot{\mathrm{x}} \\
\cdots \\
\cdots \\
\mathrm{X} \\
\cdots\end{array}$ & $\begin{array}{l}\mathrm{X} \\
\mathrm{X} \\
\mathrm{X} \\
\cdots \\
\cdots\end{array}$ & $\begin{array}{l}\cdots \\
\cdots \\
\cdots \\
\cdots \\
\cdots \\
\cdots \\
\cdots\end{array}$ & $\begin{array}{l}\cdots \\
\mathrm{x} \\
\cdots \\
\mathrm{X} \\
\mathrm{x}\end{array}$ & $\begin{array}{l}\mathrm{x} \\
\cdots \\
\mathrm{x} \\
\cdots \\
\mathrm{x} \\
\mathrm{x}\end{array}$ & $\mid \begin{array}{l}\cdots \\
\cdots \\
\cdots \\
\cdots \\
\cdots \\
\cdots \\
\cdots \\
\cdots\end{array}$ & $\begin{array}{l}\cdots \\
\cdots \\
\cdots \\
\cdots \\
\cdots \\
\cdots \\
\cdots \\
\end{array}$ & $\begin{array}{l}\cdots \\
\cdots \\
\cdots \\
\mathrm{X}\end{array}$ & $\begin{array}{l}\cdots \\
\cdots \\
\cdots \\
\mathrm{x}\end{array}$ & $\begin{array}{l}\cdots \\
\cdots \\
\cdots \\
\mathrm{X} \\
\cdots \\
\cdots \\
\cdots\end{array}$ & \begin{tabular}{l|}
$\cdots$ \\
$\cdots$ \\
$\cdots$ \\
$\cdots$ \\
$\cdots$ \\
$\cdots$ \\
$\cdots$ \\
$\cdots$
\end{tabular} & $\begin{array}{l}\cdots \\
\cdots \\
\cdots \\
\cdots \\
\cdots \\
\cdots \\
\cdots\end{array}$ & $\begin{array}{l}\underset{\mathrm{X}}{\mathrm{X}} \\
\cdots \\
\cdots \\
\cdots \\
\cdots \\
\cdots\end{array}$ \\
\hline 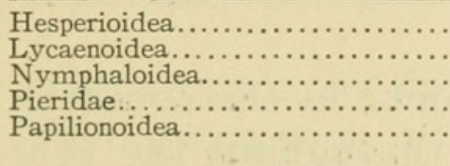 & $\begin{array}{c}\mathrm{x} \\
\cdots \\
\cdots\end{array}$ & $\begin{array}{l}\mathrm{X} \\
\cdots \\
\cdots\end{array}$ & $\cdots$ & $\begin{array}{l}\mathrm{X} \\
\mathrm{X} \\
\mathrm{x}\end{array}$ & $\begin{array}{ll}\cdots \\
\cdots \\
\cdots \\
\cdots\end{array}$ & $\begin{array}{l}\mathrm{X} \\
\cdots \\
\mathrm{X} \\
\mathrm{X}\end{array}$ & $\begin{array}{l}\dddot{\mathrm{X}} \\
\mathrm{x}\end{array}$ & $\mid \begin{array}{l}\cdots \\
\cdots \\
\cdots \\
\cdots \\
\cdots\end{array}$ & $\begin{array}{l}\mathrm{x} \\
\cdots \cdots \\
\cdots \\
\cdots \\
\cdots\end{array}$ & $\begin{array}{ll}\cdots \\
\cdots \\
\cdots \\
\cdots\end{array}$ & $\begin{array}{l}\cdots \\
\cdots \\
\cdots \\
\cdots \\
\cdots\end{array}$ & $\begin{array}{l}\cdots \\
\cdots \\
\cdots \\
\cdots\end{array}$ & $\mid \begin{array}{l}\cdots \\
\cdots \\
\cdots \\
\cdots \\
\cdots\end{array}$ & & $\begin{array}{l}\cdots \\
\cdots \\
\cdots \\
\cdots\end{array}$ \\
\hline
\end{tabular}

\section{FORMS OF PROTECTION.}

In Table II the possible forms of protection against adverse conditions are shown divided into "structural" and "external" classes; the former depend on anatomical adaptation, the latter on habit and mode of life. Here as in Table II, the division 
between microlepidoptera and the macros appears plainly and has greater biological significance than the division into moths and butterflies.

The members of the first half of the order, the microlepidoptera, show the anomalous condition of greater variety of habitat and food supply, associated with a most extraordinary uniformity in structure (excepting in leaf miners). Nearly all the exceptions to rules occur in this group. In the more specialized suborder on the other hand, one finds remarkable uniformity in habits and food but a great variety of superficial appearance.

The two most common forms of protection in Lepidopterous larvæ are (a) the development of tufts of setæ and (b) the construction of a nest or case. Silk glands are of universal occurrence but are used in many different ways with different results. The effective value of tufted setæ against birds, parasites, and predators is well known.

\section{LIFE CYCLE.}

Leaving these general considerations of lepidopterous development, a brief statement on the length of the life cycle should be included in a paper on this subject. Typically the life of a lepidopterous insect consists of (a) an egg stage, the egg simple in structure and seldom concealed; (b) the larval period, of five to seven instars; (c) the pupal condition, protected by a cocoon, or, in form, a chrysalis; and (d) the adult relatively constant in structure, and various in appearance like the larva.

The number of broods is limited, Table III showing the conditions in economic species in the northern States. One or two broods a year are the rule, longer or shorter life cycles being exceptional. The writer is familiar with no cycles longer than one year outside the family Cossidæ.

More than three annual broods occur only in the southern states or under conditions where breeding throughout the year is possible. Seven broods in one year in a species living in grain (Angoumois grain moth) seems to be the maximum authentic record.

The winter is usually spent as a larva, often followed immediately by the pupa in the spring without resumption of feeding. This is true in both one and two brooded species. In some single-brooded forms the egg stage is the hibernating condition 
while in a few species the pupa or adult manages to survive the winter.

The fundamental basis of lepidopterous development appears to be the combination of a universal food supply with a remarkable uniformity in structure in all stages. Thousands of species

TABLE III. BROODS AND HIBERNATION.

\begin{tabular}{|c|c|c|c|c|c|c|c|c|c|c|c|}
\hline \multirow{2}{*}{$\begin{array}{c}\text { FAMILY OR } \\
\text { SUPER-FAMILY }\end{array}$} & \multirow{2}{*}{$\begin{array}{l}\text { No. OF } \\
\text { SPP. } \\
\text { REC. }\end{array}$} & \multicolumn{5}{|c|}{ Broods } & \multicolumn{5}{|c|}{ HIBERNATION } \\
\hline & & $1 / 2$ & 1 & 2 & 3 & $4-6$ & $\mathrm{E}$ & $\mathrm{L}$ & $\mathrm{P}$ & P-A & A \\
\hline 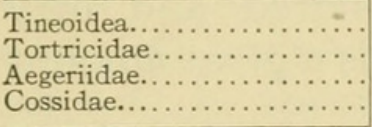 & $\begin{array}{r}6 \\
13 \\
4 \\
2\end{array}$ & $\begin{array}{l}\cdots \cdots \\
\cdots \cdots \\
\cdots\end{array}$ & $\begin{array}{r}4 \\
3 \\
4 \\
-\end{array}$ & $\begin{array}{r}2 \\
8 \\
(1) \\
\cdots\end{array}$ & $\begin{array}{l}\because-(2) \\
\cdots \cdots \\
\cdots\end{array}$ & $\begin{array}{c}(2) \\
\cdots \cdots \\
\cdots \cdots \\
\cdots \cdots \\
\end{array}$ & $\begin{array}{c}\cdots \\
3 \\
\cdots \cdots \\
\cdots \cdots\end{array}$ & $\begin{array}{l}3 \\
6 \\
4 \\
2\end{array}$ & $\begin{array}{c}2 \\
3 \\
\cdots \cdots \\
\cdots\end{array}$ & $\begin{array}{l}\cdots \cdots \\
\cdots \cdots \\
\cdots \cdots \\
\cdots \cdots\end{array}$ & $\begin{array}{l}\cdots \cdots \\
\cdots \cdots \\
\cdots \cdots\end{array}$ \\
\hline 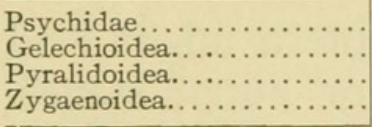 & $\begin{array}{r}1 \\
2 \\
17 \\
1\end{array}$ & & $\begin{array}{c}1 \\
4 \\
4 \\
\cdots\end{array}$ & $\begin{array}{c}\cdots \cdots \\
8 \\
1\end{array}$ & $\begin{array}{c}\because 1-(1) \\
3 \\
\cdots\end{array}$ & $\begin{array}{c}(1) \\
(8) \\
\cdots \cdots\end{array}$ & $\begin{array}{c}1 \\
\cdots \cdots \\
\cdots \cdots \\
\cdots \cdots\end{array}$ & $\begin{array}{c}\cdots \\
1 \\
8 \\
\cdots \cdots\end{array}$ & $\begin{array}{c}\cdots \cdots \\
3 \\
1\end{array}$ & $\begin{array}{l}\cdots \cdots \\
\cdots \cdots \\
\cdots \cdots \\
\cdots \cdots\end{array}$ & $\begin{array}{l}\ldots \cdots \\
\cdots \cdots \\
\cdots \cdots \\
\cdots \cdots\end{array}$ \\
\hline 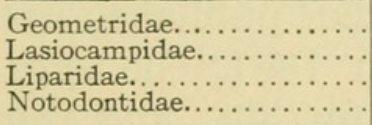 & $\begin{array}{l}7 \\
2 \\
5 \\
3\end{array}$ & & $\begin{array}{l}6 \\
2 \\
5 \\
3\end{array}$ & $\begin{array}{c}1 \\
\cdots \cdots \\
(1)\end{array}$ & $\begin{array}{l}\cdots \cdots \\
\cdots \cdots \\
\cdots \cdots \\
\cdots \cdots\end{array}$ & & $\begin{array}{r}4 \\
2 \\
4 \\
- \\
-\end{array}$ & $\begin{array}{c}1 \\
\cdots \\
1 \\
1\end{array}$ & $\begin{array}{c}1 \\
\cdots \cdots \\
2\end{array}$ & \begin{tabular}{l|}
$\cdots \cdots$ \\
$\cdots \cdots$ \\
$\cdots \cdots$ \\
$\cdots \cdots$
\end{tabular} & $\begin{array}{l}\cdots \cdots \\
\cdots \cdots \\
\cdots \cdots \\
\cdots \cdots\end{array}$ \\
\hline 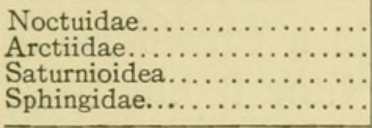 & $\begin{array}{r}18 \\
5 \\
3 \\
6\end{array}$ & & $\begin{array}{l}6 \\
4 \\
3 \\
6\end{array}$ & $\begin{array}{r}10 \\
1 \\
(2) \\
\end{array}$ & $\begin{array}{c}1 \\
\cdots \cdots \\
\cdots \cdots \\
\cdots \cdots \\
\end{array}$ & $\begin{array}{c}(4) \\
\cdots \cdots \\
\cdots \cdots \\
\cdots \cdots \\
\end{array}$ & $\begin{array}{c}1 \\
\cdots \\
1 \\
\cdots\end{array}$ & $\begin{array}{c}4 \\
5 \\
\ldots \cdots \\
\cdots \cdots \\
\end{array}$ & $\begin{array}{c}7 \\
\cdots \\
2 \\
6\end{array}$ & $\begin{array}{c}2 \\
\ldots \ldots \\
\cdots \cdots \\
\cdots \cdots \\
\end{array}$ & $\begin{array}{c}1 \\
\cdots \cdots \\
\cdots \cdots \\
\cdots \cdots \\
\cdots\end{array}$ \\
\hline 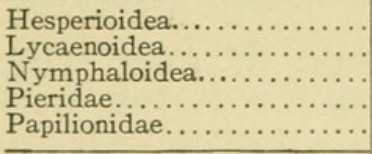 & $\begin{array}{l}1 \\
1 \\
3 \\
1\end{array}$ & & & $\begin{array}{c}\cdots \cdots \\
\cdots \\
i \\
i\end{array}$ & $\begin{array}{c}\cdots \cdots \\
\cdots \\
\cdots \\
\cdots \\
\cdots\end{array}$ & $\begin{array}{c}(1) \\
\cdots \\
\cdots \cdots \\
(3) \\
\cdots \cdots\end{array}$ & $\begin{array}{l}\cdots \cdots \\
\cdots \cdots \\
\cdots \cdots \\
\cdots \cdots \\
\cdots \cdots\end{array}$ & $\mid$\begin{tabular}{l|}
$\cdots \cdots$ \\
$\cdots \cdots$ \\
$\cdots \cdots$ \\
$\cdots \cdots$ \\
$\cdots$
\end{tabular} & $\begin{array}{l}\cdots \cdots \\
\cdots \\
\cdots \\
\cdots \\
\cdots \\
\cdots \\
\end{array}$ & $\begin{array}{l}\cdots \cdots \\
\cdots \cdots \\
\cdots \cdots \\
\cdots \cdots \\
\ldots\end{array}$ & $\begin{array}{c}\cdots \cdots \\
1 \\
\cdots \cdots\end{array}$ \\
\hline Total (Nearctic).......... & 101 & 2 & 51 & 33 & 9 & ...... & 16 & 36 & 27 & 2 & 2 \\
\hline (Subtropical or protected) & & & & (4) & (3) & (19) & & & & $\ldots$ & $\cdots \cdots$ \\
\hline
\end{tabular}

NotE-Parentheses indicate the life history in the southern states or under indoor or stored-product conditions.

E-Egg; L-Larva; P-Pupa; P-A-Emergence during hibernation reported; A-Adult.

have evolved, all different in appearance, armature, and superficial characters, but remarkably alike in functional external organs of ingestion and locomotion. The "butterfly" is the proverbial example of superficiality but the lepidopterous larva and adult have such a healthy, tremendously vital basis on which to build that they must be considered in every sense successfully adapted to their world. 


\section{$2 \mathrm{BHL}$ Biodiversity Heritage Library}

Fracker, Stanley Black. 1920. "5. The Life Cycle of the Lepidoptera." Annals of the Entomological Society of America 13, 167-173.

https://doi.org/10.1093/aesa/13.2.167.

View This Item Online: https://www.biodiversitylibrary.org/item/43848

DOI: https://doi.org/10.1093/aesa/13.2.167

Permalink: https://www.biodiversitylibrary.org/partpdf/193526

\section{Holding Institution}

Smithsonian Libraries

\section{Sponsored by}

Smithsonian

\section{Copyright \& Reuse}

Copyright Status: NOT_IN_COPYRIGHT

This document was created from content at the Biodiversity Heritage Library, the world's largest open access digital library for biodiversity literature and archives. Visit BHL at https://www.biodiversitylibrary.org. 